\title{
PENGEMBANGAN EKOWISATA BAHARI BERBASIS SUMBERDAYA PULAU- PULAU KECIL DI PULAU SAYAFI DAN LIWO, KABUPATEN HALMAHERA TENGAH
}

\author{
MARINE RESOURCE BASED ECOTOURISM DEVELOPMENT OF SMALL ISLANDS \\ IN SAYAFI AND LIWO ISLAND, CENTRAL HALMAHERA
}

\author{
Kismanto Koroy ${ }^{1}$, Fredinan Yulianda ${ }^{2}$, Nurlisa A. Butet ${ }^{2}$ \\ ${ }^{1}$ Ilmu Kelautan Universitas Pasifik Morotai \\ ${ }^{2}$ Departemen Manajemen Sumberdaya Perairan \\ Fakultas Perikanan dan Ilmu Kelautan, Institut Pertanian Bogor \\ Korespondensi : kismantokoroy@gmail.com
}

\begin{abstract}
The coastal areas in Sayafi and Liwo islands have the potential of natural resources that are classified as still quite high. The potential of natural resources owned by the two islands reflected on coral reefs, reef fish, ornamental fish, seagrass beds and fisheries. In addition to ecological function, this ecosystem also have a high aesthetic value to the development of marine tourism. The purpose of this study is to determine the suitability index and carrying capacity of the marine ecotourism for the type of diving and snorkeling activities that can be developed on the island Sayafi and Liwo Patani subdistrict of North Central Halmahera in North Maluku province. The results showed that the suitability index of marine ecotourism Sayafi and Liwo islands are in the appropriate category and very appropriate category with the capacity for this type of diving tourism activities 260 people/day in the area of the utilization is equal to 18.07 ha, and for snorkel tour with the utilization is equal to 16.01 ha area, tourists can accommodate as many as 231 people/ day. So, the total tourists who can fit both types of tourist activities is equal to 491 people/day.
\end{abstract}

Keyword: carrying capacity, marine ecotourism, natural resource, small island

\begin{abstract}
ABSTRAK
Kawasan pesisir pulau Sayafi dan Liwo memiliki potensi sumberdaya alam hayati yang tergolong masih cukup tinggi. Potensi sumberdaya alam yang dimiliki kedua pulau ini dapat dilihat pada ekosistem terumbu karang, ikan karang, ikan hias, padang lamun dan perikanan. Selain memiliki fungsi ekologis, ekosistem ini juga memiliki nilai estetika yang tinggi untuk pengembangan wisata bahari (marine tourism). Tujuan dari penelitian ini adalah menentukan kelas kesesuaian dan daya dukung ekowisata bahari untuk jenis kegiatan diving dan snorkeling yang dapat di manfaatkan di pulau Sayafi dan Liwo Kecamatan Patani Utara Kabupaten Halmahera Tengah Provinsi Maluku Utara. Hasil penelitian menunjukkan bahwa kelas kesesuaian ekowisata bahari pulau Sayafi dan Liwo berada dalam kategori sesuai dan sangat sesuai, dengan daya tampung untuk jenis kegiatan wisata diving sebanyak 260 orang/hari dengan area pemanfaatan sebesar 18.07 ha, dan untuk wisata snorkeling dengan area pemanfaatan sebesar 16.01 ha, mampu menampung wisatawan sebanyak 231 orang/hari. Dengan demikian total wisatawan yang dapat ditampung kedua jenis kegiatan wisata sebesar 491 orang/ hari.
\end{abstract}

Kata kunci: daya dukung, ekowisata bahari, pulau kecil, sumberdaya alam 


\section{PENDAHULUAN}

Ekowisata merupakan suatu bentuk perjalanan yang bertanggung jawab ke wilayah-wilayah yang masih alami dengan tujuan konservasi atau melestarikan lingkungan dan memberi penghidupan pada penduduk lokal serta melibatkan unsur pendidikan (TIES 2015). Pengelolaan ekowisata bahari yang berkelanjutan harus mempertimbangkan aspek ekologi yang menjadi objek bagi suatu kegiatan, dengan melibatkan unsur sosial sebagai pelaku wisata dalam pengelolaan, sehingga dapat memberikan manfaat secara ekonomi. (Lindberg \& Hawkins 1995) menyatakan bahwa ekowisata merupakan hal tentang menciptakan dan memuaskan suatu keinginan akan alam, tentang mengeksploitasi potensi wisata untuk konservasi dan pembangunan dan tentang mencegah dampak negatifnya terhadap ekologi, kebudayaan dan keindahan. Rumusan ekowisata juga dikemukakan oleh Hector Ceballos-Lascurain pada tahun 1987 yang menyatakan bahwa ekowisata adalah perjalanan ke tempat-tempat yang masih alami dan relatif belum terganggu atau tercemari dengan tujuan untuk mempelajari, mengagumi dan menikmati pemandangan, flora dan fauna, serta bentuk-bentuk manifestasi budaya masyarakat yang ada, baik dari masa lampau maupun masa kini (Wikipedia 2015). Salah satu wilayah yang memiliki keindahan dan keunikan tersendiri banyak ditemukan di pulau-pulau kecil. Daya tarik pulau kecil, umumnya terdapat keunikan dan keindahan yang tersebar di wilayah pesisir dan laut, sehingga kegiatan yang tepat dikembangkan adalah ekowisata bahari. Definisi ekowisata bahari menurut Yulianda et al. (2010) sebagai suatu konsep pemanfaatan berkelanjutan sumberdaya alam pesisir dengan sistem pelayanan jasa lingkungan yang mengutamakan sumberdaya alam pesisir sebagai objek pelayanan.

Beberapa pertimbangan yang menjadi fokus ekowisata bahari di wilayah pesisir dan pulau-pulau kecil, karena kawasan pulau-pulau kecil merupakan aset wisata bahari yang sangat besar yang didukung oleh potensi geologis dan karaktersistik yang mempunyai hubungan sangat dekat dengan terumbu karang (coral reef), khususnya hard corals. Kondisi pulaupulau kecil yang tidak berpenduduk secara logika akan memberikan kualitas keindahan dan keaslian dari biodiversity yang dimilikinya, sehingga sangat menarik untuk dikembangkan sebagai ekowisata bahari seperti diving dan snorkeling. (Gossling 1999; Ross \& Wall 1999) menyatakan bahwa ekowisata dapat berkontribusi untuk menjaga keanekaragaman hayati dan fungsi ekosistem. Sitomorang \& Mirzanti (2012) menambahkan bahwa ekowisata bukan sekedar menawarkan panorama yang masih alami dan indah, ekowisata juga menyediakan proses pembelajaran untuk melindungi dan merawat alam, dan untuk meningkatkan kesejahteraan masyarakat lokal di sekitar atau di dalam daerah tujuan ekowisata.

Melihat peluang dan potensi wisata bahari Indonesia yang semakin pesat berkembang, menurut (Dahuri 2009) potensi yang dimiliki tersebut saat ini belum sepenuhnya menjadi keunggulan kompetitif bangsa Indonesia yang dapat memberikan kontribusi besar pada perekonomian nasional. Salah satu pulau-pulau kecil yang memiliki potensi yang besar untuk dijadikan kawasan ekowisata bahari berbasis pulau-pulau kecil adalah kawasan pesisir Pulau Sayafi dan Liwo. Potensi sumberdaya alam yang dapat dilihat seperti ekosistem terumbu karang, ikan karang, ikan hias, padang lamun dan perikanan. Kawasan Pulau Sayafi dan Pulau Liwo juga merupakan dapur bagi masyarakat lokal dalam memanfaatkan potensi sumberdaya alam, seperti berkebun dan perikanan untuk pemenuhan kebutuhan hidupnya. Pemanfaatan potensi sumberdaya alam pesisir dan laut di Pulau Sayafi dan Pulau Liwo merupakan suatu proses yang akan membawa suatu perubahan pada ekosistemnya. Menurut (Tsaur \& Lin 2006); Zhang \& Lei 2012) menyatakan bahwa suatu lingkungan akan sangat dipengaruhi oleh aktivitas manusia. Tekanan aktifitas manusia terhadap sumberdaya alam di pulau kecil akan berdampak pada keberlanjutan ekologi.

Bengen et al. (2012), menjelaskan bahwa pulau kecil memiliki ciri-ciri biogeofisik seperti, ukuran pulau yang kecil dan terpisah dari pulau induk/pulau besar, memiliki sumberdaya air tawar yang terbatas, peka dan rentan terhadap pengaruh eksternal, memiliki keanekaragaman hayati terestrial rendah, namun memiliki sejumlah jenis endemik, keanekaragaman hayati laut tinggi, variasi iklim kecil, area perairan lebih luas dari area daratan, serta tidak mempunyai hinterland yang jauh dari pantai. Ciri-ciri biogeofisik pulau-pulau kecil 
seperti ini, tentu sangat kompleks terhadap pembangunan yang nanti dimanfaatkan di Pulau Sayafi dan Pulau Liwo. Oleh karena itu, rencana pengelolaan ekowisata bahari di Pulau Sayafi dan Liwo memerlukan suatu konsep pengelolaan yang berbasis pada pulau-pulau kecil dengan pendekatan ekologi. Permenbudpar No. KM.67/ UM.001/ MKP/ 2004, menjelaskan bahwa implikasi pengembangan kegiatan wisata maupun penyediaan penunjang kepariwisataan di pulau-pulau kecil akan berdampak pada lingkungan fisik, sosial, budaya dan ekonomi pulau-pulau kecil. Oleh karena itu diperlukan pertimbangan-pertimbangan khusus dalam pengembangan kegiatan pariwisata di pulau-pulau kecil.

Upaya pencegahan laju kerusakan ekosistem pesisir dan laut dengan pola pemanfaatan yang berlebihan, maka hal yang paling utama dalam konsep pemanfaatan sumberdaya untuk ekowisata bahari memerlukan model pengelolaan yang didasarkan pada pendekatan Daya Dukung Kawasan (DDK) dan koreksi Daya Dukung Adaptif (DDA) terhadap penggunaan sumberdaya lingkungan menjadi penting untuk dikaji secara ilmiah sehingga diharapkan dapat menghasilkan suatu arahan pengelolaan dengan konsep ekowisata bahari yang berkelanjutan.

Tujuan dari penelitian ini adalah menentukan kelas kesesuaian ekowisata bahari serta mengkaji DDK dan DDA sebagai ekowisata bahari untuk jenis kegiatan diving dan snorkeling yang dapat di manfaatkan di pulau Sayafi dan Liwo Kecamatan Patani Utara Kabupaten Halmahera Tengah Provinsi Maluku Utara.

\section{METODE PENELITIAN}

Penelitian ini dilaksanakan dalam dua tahapan. Tahap awal dimulai pada bulan Agustus 2013 untuk survei lokasi dan data awal. Sedangkan tahap kedua dilaksanakan selama tiga bulan, dimulai pada bulan Juli -September 2014. Lokasi penelitian berada di Pulau Sayafi dan Pulau Liwo. Secara administratif kedua pulau ini termasuk dalam wilayah Kecamatan Patani Utara Kabupaten Halmahera Tengah, Provinsi Maluku Utara. Peta lokasi penelitian dapat dilihat pada Gambar 1.

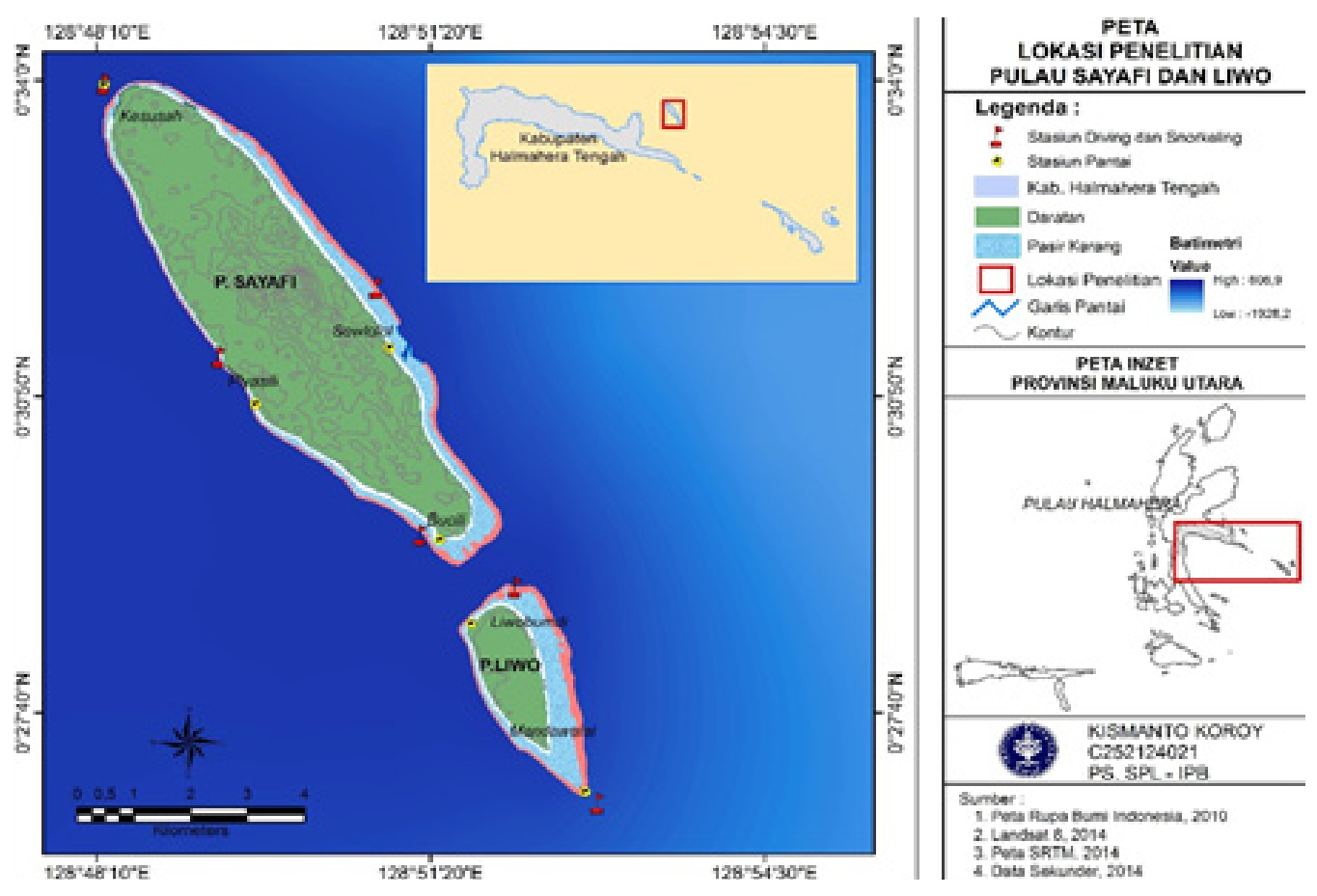

Gambar 1 Peta Lokasi Penelitian 
Sumber dan jenis data yang diperoleh dalam penelitian ini adalah data primer dan data sekunder. Data primer merupakan data yang dikumpulkan secara langsung dilapangan. Pengambilan data primer dengan menggunakan metode purposive sampling yaitu dengan pertimbangan dan alasan tertentu seperti penentuan lokasi pengambilan data. Data sekunder adalah data yang diperoleh dari penelusuran terhadap laporan-laporan hasil penelitian dan hasil kegiatan di lokasi yang sama, publikasi ilmiah, peraturan daerah, data dari instansi pemerintah, swasta maupun lembaga swadaya masyarakat serta data sejarah kawasan.

Pengumpulan data biofisik dilakukan berdasarkan pengamatan secara langsung di lapangan. Adapun data-data yang diambil adalah sebagai berikut :

1. Kapasistas adaptif ekosistem terumbu karang

- Indeks dimensi terumbu karang

Pengukuran dimensi panjang dan lebar hamparan terumbu karang dilakukan untuk mengetahui kapasitas adaptif ekosistem terumbu karang. Pengukuran tersebut mengacu pada Subur (2012), dimana pengukuran dimensi panjang dan lebar karang dibagi ke dalam segmen-segmen. Setiap pertambahan dimensi lebar sebesar $10 \mathrm{~m}$, maka akan diikuti oleh pertambahan nilai sebesar 0.01 , dan akan mencapai nilai maksimal 1.0 pada saat dimensi lebar terumbu karang $\geq 1.000 \mathrm{~m}$. Asumsi lebar terumbu karang dengan ukuran $\geq 1.000 \mathrm{~m}$, adalah bahwa secara umum lebar terumbu karang di Indonesia untuk pulau-pulau kecil maksimal berada pada ukuran tersebut. Selanjutnya setiap pertambahan dimensi panjang mengikuti panjang garis pantai pulau terbesar pada lokasi penelitian, maka nilai dimensi panjang juga akan bertambah sebesar 0.01 dan akan mencapai nilai maksimal sebesar 1.0 pada panjang hamparan terumbu karang (Subur 2012).

- Tutupan terumbu karang dan lifeform

Pengambilan data dilakukan dengan petunjuk English et al. (1997), dimana ukuran transek sepanjang $50 \mathrm{~m}$, mengikuti arah garis pantai. Lokasi pengambilan data ditetapkan setelah melihat hasil yang diperoleh melalui teknik manta-tow, dimana pada setiap lokasi ditentukan 1 titik untuk dijadikan lokasi peletakan transek dengan teknik Line Intercept Transect (LIT). Setiap lifeform karang yang dilewati transek dicatat dan difoto yang selanjutnya akan di identifikasi menurut kondisi dan taksonnya. Dari data tersebut akan diketahui persentase tutupan karang, dominasi lifeform, jumlah jenis lifeform dan kategori karang mati dan karang hidup.

- Ikan karang

Pengamatan ikan karang dengan menggunakan teknik visual sensus yang terdapat pada setiap transek LIT, yaitu ikan-ikan karang yang berada pada jarak $2.5 \mathrm{~m}$ dari sisi kiri dan kanan garis transek. Luas bidang pengamatan yaitu $250 \mathrm{~m}^{2}(5 \mathrm{x}$ $\left.50 \mathrm{~m}^{2}\right)$; English et al. (1997). Kegiatan sensus dimulai setelah periode normal (tenang) \pm 15 menit setelah transek dipasang. Data yang diperoleh dicatat pada kertas atau lembaran data yang sudah disediakan. Untuk keperluan identifikasi jenis, maka ikan dan biota karang lainnya difoto dengan menggunakan kamera underwater.

- Kedalaman terumbu karang

Kedalaman terumbu karang diukur secara manual dengan menggunakan tali yang sudah diberi tanda ukuran (meter) dan di ikat dengan pemberat. Pengukuran dilakukan diatas kapal di saat sedang dalam lego jangkar atau dalam posisi normal.

- Jarak pemukiman dengan ekosistem terumbu karang

Pengukuran jarak ekosistem terumbu karang dengan pemukiman penduduk, dibantu dengan menggunakan GPS dan Sistem Informasi Geografis (SIG).

\section{Parameter Kualitas Perairan}

Data parameter kualitas perairan yang diukur antara lain : salinitas perairan, suhu perairan, $\mathrm{pH}$ perairan. Alat yang digunakan untuk mengukur parameter kualitas perairan dengan menggunakan Horiba tipe $\mathrm{U}-52$.

\section{Analisis data}

Analisis kapasistas adaptif ekosistem terumbu karang

Komponen analisis yang digunakan untuk mengetahui kapasitas adaptif 
ekosistem terumbu karang, meliputi Indeks Dimensi Terumbu Karang (IDTK), tutupan karang (\%), dominasi lifeform, jumlah jenis lifeform, jumlah spesies ikan karang, kedalaman terumbu karang, dan jarak pemkiman dengan ekosistem terumbu karang $(\mathrm{km})$. Persamaan yang digunakan untuk menghitung kapasitas adaptif terumbu karang dengan menggunakan formula menurut Subur (2012).

$$
K T P K=\sum\left[\frac{N i}{N \max }\right] \times 100 \%
$$

dimana :

KPTK = Nilai Kapasitas ekosistem terumbu karang ke-i;

$\mathrm{Ni} \quad=$ Total nilai parameter hasil pengukuran;

Nmax $=$ Nilai maksimum parameter pada ekosistem terumbu karang.

Nilai kapasitas ekosistem terumbu karang beradapa pada kisaran antara 0.01.0, dengan lima kategori yang terdiri dari "sangat rendah $(0.0 \leq \mathrm{KPTk} \leq 0.2)$ ". "Rendah $(0.2<\mathrm{KPTk} \leq 0.4)$ ". "Sedang $(0.4<\mathrm{KPT} \leq 0.6)$ ". "Tinggi $(0.6<\mathrm{KPTk} \leq 0.8)$ ". "Sangat Tinggi $(0.8<$ KPTk $\leq 1.0)$ ".

\section{Indeks dimensi terumbu karang}

Hasil pengukuran dimensi panjang dan lebar terumbu karang, selanjutnya penghitungan indeks dimensi terumbu karang menggunakan persamaan Subur (2012).

$$
I D T K=\sum\left[\frac{N L}{S L}\right]+\sum\left[\frac{N P}{S P}\right]
$$

dimana :

IDTK = Indeks Dimensi Terumbu Karang;

$\mathrm{NL}=$ Jumlah total seluruh nilai segmen dimensi lebar;

SL = Jumlah total segmen dimensi Lebar;

NP = Jumlah total seluruh nilai segmen dimensi Panjang

$\mathrm{SP}=$ Jumlah total segmen dimensi Panjang.

Nilai IDTK berada pada kisaran antara 0.0-2.0, yang terdistribusi kedalam lima kategori yaitu "SangatRendah $(0.0 \leq \mathrm{IDTK} \leq 0.4)$ ". "Rendah $\quad(0.4<$ IDTK $\leq 0.8)$ ". "Sedang $(0.8<$ IDTK $\leq 1.2)$ ". "Tinggi $\quad(0.2<$ IDTK $\leq 0.6)$ ". "Sangat Tinggi (1.6<IDTK $\leq 2.0)$ ".

2. Analisis tutupan karang

Analisis persentase tutupan karang hidup dengan menggunakan metode Line Intersect Transect (LIT) berdasarkan persamaan (English et al. 1997).

$$
\%_{\text {coverage }}=\frac{L i}{L} \times 100 \%
$$

Interpretasi kriteria persentase tutupan komunitas karang berdasarkan (Gomez \& Yap 1988) in (Setyobudiandi et al. 2009) dengan kategori, 0.0-24.9\% (buruk), 5.0-49.9\% (sedang), 50.0-74.9\% (bagus), dan $75.0-100.0 \%$ (memuaskan).

3. Analisis ikan karang

Analisis kelimpahan ikan karang dihitung dengan menggunakan rumus yang dikemukakan oleh Odum (1994) sebagai berikut :

$$
X=\frac{\sum X_{i}}{n} \times 100
$$

dimana :

$X \quad=$ kelimpahan ikan;

$\sum X i=$ jumlah ikan pada stasiun pengamatan ke-i;

$n \quad=$ luas terumbu karang yang diamati $\left(\mathrm{m}^{2}\right)$;

Analisis kesesuaian kawasan ekowisata bahari

Analisis kesesuaian yang dilakukan dalam penelitian ini hanya difokuskan untuk peruntukan kawasan ekowisata bahari (jenis kegiatan diving dan snorkeling). Pemberian bobot berdasarkan tingkat kepentingan suatu parameter, sedangkan pemberian skor berdasarkan kualitas setiap parameter. Rumus yang digunakan untuk menghitung nilai kesesuaian ekowisata bahari adalah (Yulianda et al. 2010) :

$$
I K W=\sum\left[N_{i} / N_{m a k s}\right] \times 100 \%
$$

dimana :

$I K W \quad=$ Indeks kesesuaian wisata;

$\mathrm{Ni} \quad=$ Nilai parameter ke-i (Bobot $\mathrm{x}$ Skor); Nmaks = Nilai maksimum dari suatu kategori wisata;

Penentuaan kelas kesesuaian lahan untuk kategori tertentu dapat dilakukan dengan menghitung nilai interval kelas dari masing-masing nilai kesesuaian lahan ekowisata. Pembagian kelas kesesuaian ekowisata bahari mengacu pada (Yulianda 2007) dibagi menjadi tiga kelas kesesuaian yaitu ; Sangat sesuai (S1) dengan IKW $>75 \%$, Sesuai (S2) IKW 50-75\%, dan Tidak 
sesuai (TS) dengan IKW $<50 \%$. Setelah membandingkan nilai interval kelas, selanjutnya pemetaan kelas kesesuaian menggunakan analisis keruangan (spatial analysis). Penggunaan analisis keruangan untuk mengidentifikasi pemanfaatan ruang dilakukan dengan pendekatan SIG dengan menggunakan software ArcGIS.

\section{Analisis daya dukung kawasan}

DDK adalah jumlah maksimum pengunjung yang secara fisik dapat ditampung dikawasan yang disediakan pada waktu tertentu tanpa menimbulkan gangguan pada alam dan manusia, perhitungan DDK mengacu pada Yulianda et al. (2010).

$$
D K K=K x L_{p} / L_{t} x W_{t} / W_{p}
$$

Potensi ekologis pengunjung dalam melakukan aktifitas berdasarkan unit area dan waktu yang di habiskan dalam setiap unit kegiatan, dapat dilihat pada Tabel 1 dan 2.

\section{Analisis daya dukung adaptif}

DDA bertujuan untuk menilai kemampuan suatu ekosistem dalam mentolerir aktifitas pengunjung dalam pemanfaatan jenis kegiatan tertentu. Untuk menghasilkan nilai DDA, terlebih dahulu harus memperoleh nilai DDK dan indeks dimensi setiap ekosistem. Perhitungan yang digunakan untuk mengetahui nilai DDA dengan modifikasi persamaan Subur (2012):

$$
D D K A_{i}=D D K_{i} \times I D E_{i}
$$

Keterangan:

$\mathrm{DDA}_{\mathrm{i}}=$ Daya Dukung Adaptif ke-i;

DDK $_{i}=$ Daya Dukung Kawasan ke-i;

$\mathrm{IDE}_{\mathrm{i}}=$ Indeks Dimensi Ekosistem ke-i.

Tabel 1 Potensi ekologis pengunjung $(\mathrm{K})$ dan luas area kegiatan (Lt)

\begin{tabular}{lccc}
\hline Jenis Kegiatan & K (Orang) & $\begin{array}{c}\text { Unit area } \\
(\mathbf{L t})\end{array}$ & Keterangan \\
\hline Selam & 2 & $2000 \mathrm{~m}^{2}$ & Setiap 2 orang dalam 200 m x 10 m \\
Snorkeling & 1 & $500 \mathrm{~m}^{2}$ & Setiap 1 orang dalam 100 m x 5 m \\
\hline
\end{tabular}

Sumber : Yulianda et al. (2010)

Tabel 2 Waktu yang dibutuhkan untuk setiap kegiatan wisata

\begin{tabular}{lcc}
\hline Jenis Kegiatan & $\begin{array}{c}\text { Waktu yang dibutuhkan } \\
\text { Wp-(jam) }\end{array}$ & Total waktu $\mathbf{1}$ hari Wt-(jam) \\
\hline Selam & 2 & 8 \\
Snorkeling & 3 & 6 \\
\hline
\end{tabular}

Sumber : Yulianda et al. (2010)

\section{HASIL DAN PEMBAHASAN}

\section{Kondisi fisik perairan}

Parameter fisik lingkungan perairan pulau Sayafi dan pulau Liwo yang diamati adalah parameter perairan yang terkait dengan pengembangan wisata diving dan snorkeling seperti, suhu, salinitas, kecerahan dan arus.

Pengukuran suhu perairan selama pengambilan data dilakukan memiliki nilai berkisar antara $27{ }^{\circ} \mathrm{C}$ hingga $29{ }^{\circ} \mathrm{C}$. Nybakken (1988) menjelaskan kisaran suhu untuk pertumbuhan terumbu karang yang dapat tumbuh subur dan mendekati ekstrim dan masih dapat ditoleransi berada pada suhu antara $23^{\circ} \mathrm{C}-25^{\circ} \mathrm{C}$ dan pada suhu ekstrim yang masih dapat ditoleransi berkisar antara $36^{\circ} \mathrm{C}-40^{\circ} \mathrm{C}$.

Hasil pengukuran salinitas pada enam lokasi pengamatan berada pada kisaran 34\%o. Nilai parameter suhu perairan dari hasil pengukuran, secara umum menunjukkan fenomena alami, dimana makin tinggi pergerakan matahari memberikan nilai yang lebih besar. Hal ini juga dipengaruhi karena tidak adanya muara sungai yang mengalir langsung ke perairan laut pulau Sayafi dan Liwo. Suatu Perairan dengan dominasi komunitas mangrove, umumnya massa air yang masuk 
ke perairan laut (outflow) memiliki kadar garam yang relatif lebih rendah (rata-rata $32 \%$ o) dibandingkan kadar pada perairan dengan substrat berbatu berkisar 32-35 (DKP Provinsi Malut 2012).

Kecerahan perairan di pulau Sayafi dan pulau Liwo dari hasil penelitian berkisar antara 85\%-95\% dengan kedalaman 3-10m. Pengukuran parameter kecerahan perairan dilakukan pada waktu siang hari dengan kondisi cuaca cerah dan tidak berombak. Pengukuran tingkat kecerahan pada kolom air untuk melihat kemampuan suatu perairan dalam meloloskan cahaya matahari. Tingkat kecerahan dengan kondisi perairan yang jernih dan cahaya yang cukup, tentu menjadi faktor paling penting untuk proses fotosintesis (Nybakken 1988).

Arus merupakan gerakan mengalir suatu massa air yang disebabkan oleh tiupan angin, perbedaan dalam densitas air laut atau pasang surut (Nontji 2009). Pola arus yang terjadi di sekitar wilayah perairan Halmahera Tengah menunjukkan pola yang berfluktuasi. Pola fluktuasi tersebut lebih banyak dipengaruhi oleh pergerakan massa air di laut Samudera Pasifik untuk wilayah sekitar khatulistiwa (DKP Provinsi Maluku Utara 2008). Hasil pengukurun kecepatan arus di pulau Sayafi dan pulau Liwo berada pada kisaran $0.05-0.43 \mathrm{~m} /$ detik.

\section{Kondisi terumbu karang}

Formasi terumbu karang di Pulau Sayafi dan Pulau Liwo tergolong dalam tipe karang tepi (fringing), dengan dataran karang yang bervariasi. Friging reef adalah terumbu karang yang berada dekat dan sejajar dengan garis pantai (Nurjanah et al. 2011). Pertumbuhan terumbu karang tepi yang berada dekat dengan daratan dan berkembang di sekeliling pulau-pulau kecil dapat menerima pukulan ombak, sehingga menopang pertumbuhan karang dengan baik. English et al. (1997), mengklasifikasi pertumbuhan karang ke dalam enam kategori yaitu acropora, non-acropora, dead coral, abiotic, soft coral dan other. Untuk kepentingan analisis ekowisata bahari, maka bentuk pertumbuhan karang seperti klasifikasi tersebut diatas, kemudian dikelompokkan menjadi 5 (lima) kategori berdasarkan data yang ditemukan pada lokasi pengamatan, diantaranya hard coral, soft coral, dead coral, abiotic dan other. Kategori karang hidup terdiri dari acropora, non-acropora dan soft coral, karang rusak terdiri dari dead coral, dead coral with algae, untuk abiotik terdiri dari sand dan rubble sedangkan kategori other terdiri dari turf algae, bottle brush dan assemblage.

Pemanfaatan ekowisata bahari dengan menikmati ekosistem terumbu karang sebagai objek dalam kegiatan diving dan snorkeling. Tujuan pengunjung dalam melakukan penyelaman tidak hanya sebatas untuk menikmati hard coral tetapi soft coral juga menjadi objek dalam wisata diving dan snorkeling. Nontji (2009) menyatakan bahwa dari segi estetika terumbu karang yang masih utuh menampilkan pemandangan yang sangat indah, jarang dapat ditandingi oleh ekosistem lain (Gambar 2).

Gambar 2 memperlihatkan komposisi tutupan ekosistem terumbu karang di Pulau Sayafi dan Liwo berada pada kategori bagus dan memuaskan. Namun demikian, pada beberapa titik pengamatan ditemukan karang dalam kondisi kurang baik. Hasil penyelaman pada enam lokasi pengamatan ditemukan karang dalam kondisi rusak (dead coral), seperti di Mandawalai dan Bucili. Persentase data kerusakan dapat dilihat pada. Kerusakan karang tersebut diindikasikan karena terjadinya aktivitas penangkapan ikan dengan menggunakan alat tangkap ikan yang tidak ramah lingkungan. Hal ini dibuktikan dengan ditemukannya patahan-patahan karang dengan jumlah yang cukup besar. Tahun 2008 sebuah penelitian yang dilakukan oleh DKP Provinsi Maluku Utara juga menemukan karang dengan kondisi rusak. Namun dalam laporan penelitiannya tidak mencantumkan angka persentase tutupan karang hidup dan karang yang rusak. Selanjutnya DKP Provinsi Maluku Utara (2008), juga mengatakan bahwa hancurnya karang di Pulau Sayafi dan Liwo lebih banyak diakibatkan oleh penggunaan bahan peledak. Penelitian lain yang dilakukan oleh Gladstone et al. (2013) menjelaskan bahwa pembangunan infrastruktur pendukung ekowisata yang dibangun di daerah pesisir, secara tidak langsung dapat memberikan pengaruh lingkungan dan ekosistem perairan laut.

Parameter penting lain dalam penentuan kelas kesesuaian ekowisata bahari untuk jenis kegiatan wisata diving dan snorkeling, adalah jenis lifeform. Jenis lifeform yang digunakan dalam penentuan kegiatan ekowisata bahari diacu dalam English et al. (1997). Keseluruhan jenis lifeform yang ditemukan pada 6 lokasi pengamatan berjumlah 16 jenis lifeform. Jenis lifeform terbanyak ditemukan di 
Liwobumdi dan Bucili dengan jumlah lifeform masing-masing sebanyak 14 . Lifeform terendah ditemukan di Mandawalai dan Kesusah dengan jumlah lifeform sebanyak 12. Kehadiran jenis lifeform yang sama, sebagian besar ditemukan di semua lokasi pengamatan. Faktor fisik lingkungan perairan seperti suhu, salinitas, kecerahan dan kecepatan arus pada lokasi pengamatan, menjadi parameter penting bagi pertumbuhan karang (Nybakken 1998). Parameter fisik lingkungan perairan pada lokasi pengamatan memiliki nilai perbedaan yang tidak terlalu signifikan.

Kehadiran acropora pada enam lokasi pengamatan terdiri dari branching, tabular, digitate dan submassive. Untuk non-acropora memiliki pertumbuhan yang terdiri dari submassive, branching, massive, millepora dan foliose. Sedangkan kehadiran soft coral pada lokasi pengamatan hanya memiliki tutupan yang sedikit, hal ini dipengaruhi oleh keberadaan pulau yang berhadapan langsung dengan samudera Pasifik, sehingga lebih dipengaruhi oleh tekanan arus dan pasang surut air laut. Kondisi topografi terumbu karang yang berbentuk slope pada bagian dasar perairan yang terlindung dari kecepatan arus yang kuat memberikan peluang pada soft coral sehingga dapat tumbuh dengan baik.

Persentase dead coral yang diamati pada 6 lokasi pengamatan hanya terdapat di Liwobumdi dan Bucili. Dead coral tertinggi terdapat di Liwobumdi sebesar (25.61\%) dan di Bucili sebesar (4.70\%). Penutupan abiotik berdasarkan hasil pengamatan yang terdiri dari sand dan rubble, ditemukan persentase tertinggi berada di Mandawalai, sebesar $(15.67 \%)$ dan yang terendah terdapat di Liwobumdi, (10.47\%). Jenis lifeform lain yang terdiri dari turf algae, bottle brush dan assemblage termasuk dalam kategori other. Persentase penutupan tertinggi berada di Bucili, sebesar $(15.66 \%)$ dan terendah terdapat di Liwobumdi, dengan persentase sebesar $(2.39 \%)$.

Persentase potensi ekosistem terumbu karang untuk pemanfaatan ekowisata bahari merupakan parameter penting kegiatan snorkeling dan diving. Yulianda et al. (2010) menyebutkan bahwa untuk melihat kesesuaian ekowisata bahari dengan jenis kegiatan snorkeling dan diving, maka parameter tutupan komunitas karang hidup (hard coral) dan (soft coral) harus memiliki angka persentase $>50-75 \%$ yang termasuk dalam kategori sesuai dan persentase $>75 \%$ sangat sesuai. Hal ini karena salah satu tujuan pengunjung untuk wisata diving dan snorkeling adalah menikmati keindahan terumbu karang dan biota karang. Hasil analisis tutupan karang di Pulau Sayafi memiliki persentase tutupan sebesar $76.9 \%$ sedangkan di Pulau Liwo memiliki angka persentase sebesar $71.6 \%$. Dengan demikian, persentase tutupan karang di kedua pulau tersebut termasuk dalam kategori sesuai dan sangat sesuai.
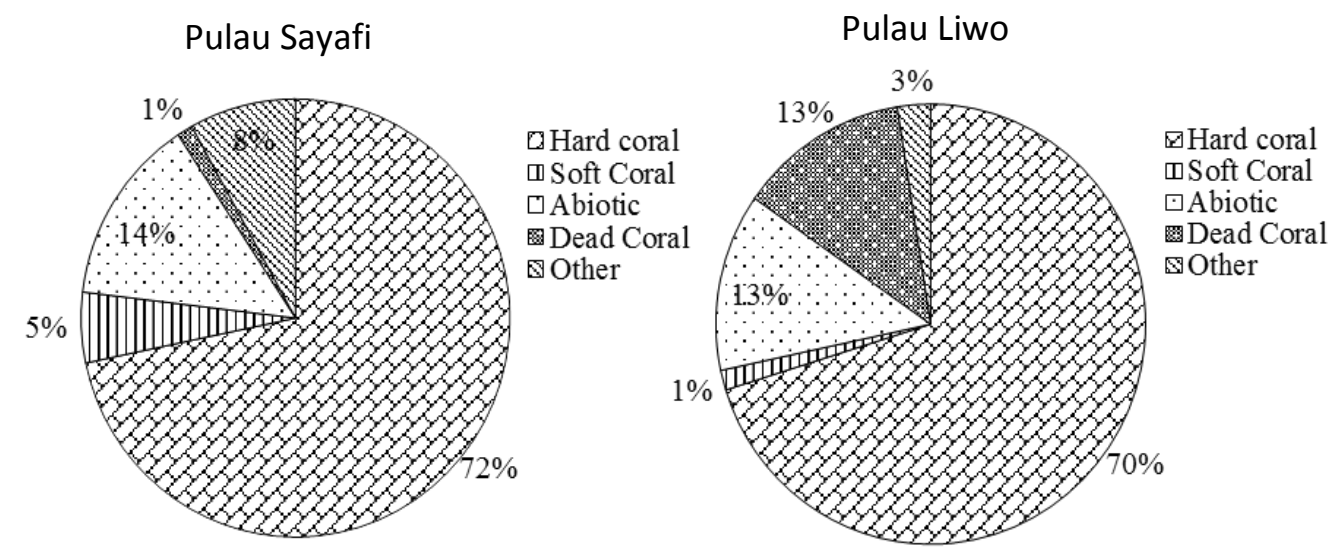

Gambar 2 Persentase tutupan terumbu karang di Pulau Sayafi dan Pulau Liwo 


\section{Ikan karang}

Kehadiran ikan karang yang hidup di ekosistem terumbu karang, merupakan bagian dari objek pemandangan dalam melakukan wisata diving dan snorkeling. Hasil pengamatan pada 6 lokasi, ditemukan sekitar 127 jenis ikan karang, yang tergolong dalam 21 famili. Persentase famili tertinggi terdapat di Sowlolol sebesar (38.5\%), dan yang terendah berada di Liwobumdi dengan total persentase (4.38\%). Persentase famili dengan kelimpahan individu tertinggi adalah pomacentridae sebanyak 2230 ekor, dengan persentase (80.77\%) sedangkan famili dengan kelimpahan individu terendah terdapat dua famili yaitu scaridae dan terapontidae berjumlah masing-masing 1 ekor, dengan persentase (0.04\%). Perbandingan persentase tutupan karang dan kelimpahan ikan karang pada lokasi pengamatan di Pulau Sayafi dan Liwo terlihat pada Gambar 3.

Potensi ekosistem terumbu karang dengan keanekaragaman jenis ikan karang pada suatu perairan merupakan satu kesatuan ekosistem. Pengembangan ekowisata bahari, untuk menentukan kelas kesesuaian kegiatan diving dan snorkeling, maka parameter penutupan karang dan jumlah jenis ikan karang menjadi sangat penting untuk di perhatikan.

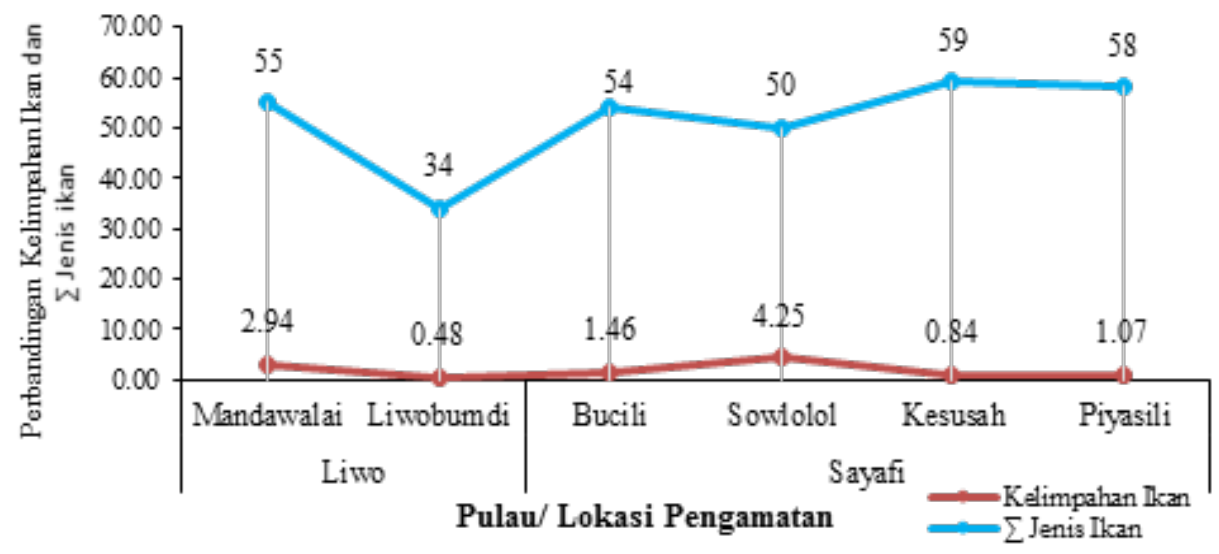

Gambar 3 Perbandingan kelimpahan ikan dan jumlah jenis ikan

\section{Kapasitas adaptif ekosistem terumbu karang}

Perhitungan kapasitas adaptif ekosistem terumbu karang dilakukan dengan menggunakan 7 parameter yaitu indeks dimensi terumbu karang, tutupan karang (\%), dominasi lifeform, jumlah jenis lifeform, jumlah spesies ikan karang, kedalaman terumbu karang (m) dan jarak dari pemukiman (km) (Tabel 3).

Persentase nilai kapasitas adaptif berada pada kisaran antara 0.59-0.80. Semakin tinggi nilai yang dimiliki parameter tersebut, maka semakin tinggi pula kapasitas adaptif ekosistem terumbu karang. Hasil tersebut menunjukkan bahwa kapasitas adaptif terumbu karang di Pulau Sayafi dan Liwo termasuk dalam kategori sedang $(0.4<\mathrm{KPTK} \leq 0.6)$ dan tinggi $(0.6<\mathrm{KPTK} \leq 0.8)$.

Analisis indeks dimensi ekosistem terumbu karang bertujuan untuk melihat penyebaran terumbu karang pada suatu kawasan tertentu. Asumsi penyebaran dengan nilai yang tinggi menunjukkan bahwa pada areal tersebut memiliki hamparan terumbu karang yang cukup luas dan menyebar secara merata, dan apabila penyebaran dengan nilai yang rendah dapat menginformasikan bahwa areal tersebut terdapat hamparan terumbu karang yang kecil. Indeks dimensi ekosistem terumbu karang juga dapat digunakan untuk menghitung daya dukung adaptif. Penyebaran ekosistem terumbu karang dengan luasan yang besar maupun, akan sangat berpengaruh terhadap daya dukung kawasan ketika dikoreksi (Subur 2012). Persentase tutupan karang yang semakin tinggi menunjukkan tingkat kesehatan dan kesuburan karang dalam kondisi baik, sehingga menjamin keberlangsungan proses ekologi bagi ekosistem terumbu karang dan biota pengisi lainya. Dominasi dan jumlah jenis lifeform mengindikasikan bahwa keanekaragaman terumbu karang pada areal tersebut. Indikator spesies ikan karang dengan jumlah yang besar dapat ketahui bahwa kondisi terumbu karang masih dalam kondisi yang bagus. Kedalaman terumbu karang dengan kondisi perairan yang cukup baik, akan memberikan pangaruh pada 
pertumbuhan ekosistem terumbu karang, sedangkan jarak pemukiman dengan ekosistem terumbu karang yang cukup jauh, akan sangat baik bagi keberlangsungan hidup terumbu karang, karena kurang mendapatkan tekanan eksternal dari aktifitas manusia. Tahir et al. (2009) menjelaskan bahwa salah satu upaya untuk meningkatkan kapasitas adaptif dari pulaupulau kecil adalah melakukan pengelolaan ekosistem pesisir, seperti terumbu karang, mangrove dan padang lamun.

Tabel 3. Hasil analisa proksimat Artemia pada semua perlakuan

\begin{tabular}{lllccccccc}
\hline \multirow{2}{*}{ Pulau } & $\begin{array}{c}\text { Lokasi } \\
\text { Pengamatan }\end{array}$ & IDTK & $\begin{array}{c}\text { PTTK } \\
\text { (\%) }\end{array}$ & DL & JJL & JJIK & KDTK & JEPP & KPTK \\
\hline \multirow{2}{*}{ Liwo } & Mandawalai & 0.5 & 81.71 & ACB & 12 & 55 & $1-8$ & \pm 20 & 0.69 \\
& Liwobumdi & 0.4 & 61.53 & ACB & 14 & 34 & $1-4$ & \pm 21 & 0.59 \\
& Bucili & 0.3 & 65.60 & CM & 14 & 54 & $1-10$ & \pm 20 & 0.70 \\
\multirow{3}{*}{ Sayafi } & Sowlolol & 0.3 & 80.27 & ACB & 13 & 50 & $1-4$ & \pm 21 & 0.59 \\
& Kesusah & 0.3 & 80.34 & CS & 12 & 59 & $1-6$ & \pm 21 & 0.69 \\
& Piyasili & 0.2 & 81.39 & ACB & 13 & 58 & $1-8$ & \pm 18 & 0.80 \\
\hline
\end{tabular}

Keterangan: IDTK = Indeks dimensi terumbu karang; PTTK (\%) = Persentase tutupan terumbu karang; DL = Dominasi lifeform; JJL = Jumlah jenis lifeform; JJIK = Jumlah jenis ikan karang; KDTK = Kedalaman terumbu karang; JEPP = Jarak ekosistem dengan pemukiman penduduk; KAETK = Kapasitas adaptif ekosistem terumbu karang; $\mathrm{T}$ = Tinggi; $\mathrm{S}$ = Sedang.

\section{Kesesuaian ekowisata bahari}

Penentuan kelas kesesuaian kawasan untuk pemanfaatan ekowisata bahari dengan jenis kegiatan wisata diving dan snorkeling dengan merujuk pada analisis kesesuaian ekowisata bahari dalam (Yulianda et al. 2010). Kesesuaian kawasan untuk jenis kegiatan diving dan snorkeling pada enam lokasi pengamatan menunjukkan bahwa nilai kesesuaian berada pada kategori kelas sangat sesuai (S1) dan kelas sesuai (S2).

\section{Wisata diving}

Parameter yang digunakan untuk menentukan kelas kesesuaian ekowisata bahari kategori wisata diving, terdiri dari 6 parameter antara lain, kecerahan perairan, tutupan komunitas karang, jenis lifeform, jenis ikan karang, kecepatan arus dan kedalaman terumbu karang. Analisis kesesuaian berdasarkan parameter tersebut, diperoleh nilai kesesuaian ekowisata bahari di Pulau Sayafi dan Liwo untuk kategori diving. Kelemahan yang terdapat di lokasi tersebut karena pada parameter tutupan komunitas karang, jenis ikan karang dan kedalaman terumbu karang memiliki nilai tergolong rendah. Perhitungan kelas kesesuian ekowisata bahari untuk jenis kegiatan wisata diving, disajikan pada Tabel 4.
Analisis parameter kesesuaian ekowisata untuk kegiatan diving memperlihatkan tingkat kecerahan perairan di enam lokasi pengamatan, masih dalam kondisi baik, dengan nilai berkisar antara 86\%-90\%. Parameter tutupan komunitas karang dengan skor 3 (tiga), terdapat di Mandawalai, Sowlolol, Kesusah dan Piyasili. Hasil analisis menunjukkan bahwa nilai tutupan komunitas karang di Mandawalai memiliki persentase tertinggi yaitu $81.71 \%$ dan yang terendah terdapat di Liwobumdi dengan nilai persentase $61.53 \%$. Hasil pengamatan menunjukkan bahwa terumbu karang di Liwobumdi dan Bucili termasuk dalam kondisi rusak. Persentase kerusakan terumbu karang di lokasi tersebut sebesar $4.70 \%$ (Bucili) dan $25.61 \%$ (Liwobumdi). Indikasi kerusakan terumbu karang di lokasi ini, diakibatkan karena aktifitas penangkapan ikan dengan menggunakan bahan peledak.

Jenis lifeform yang ditemukan di 6 (enam) lokasi pengamatan berkisar antara 12-14 jenis lifeform. Jenis lifeform tertinggi ditemukan di Liwobumdi dan Bucili, sedangkan jenis lifeform terendah terdapat di Mandawalai dan Kesusah. Jenis ikan karang yang ditemukan pada masing-masing stasiun pengamatan hanya mencapai angka tertinggi sebanyak 59 jenis ikan karang. Kesusah dan Piyasili merupakan stasiun pengamatan yang memiliki angka tertinggi untuk jenis ikan karang, sedangkan 
Liwobumdi termasuk sebagai stasiun yang memiliki jenis ikan karang paling rendah. Hasil pengukuran pada 6 lokasi pengamatan menunjukkan kecepatan arus berkisar antara $0.05-0.43 \mathrm{~m} /$ detik. Kecepatan arus tertinggi berada di Bucili, dan yang terendah berada di Mandawalai (Gambar 4).

Peruntukan kawasan untuk kegiatan diving harus memperhatikan faktor pembatas. Menurut Yulianda (2010) kegiatan diving dapat dilakukan pada kedalaman lebih dari $6 \mathrm{~m}$. Hasil pengamatan menunjukan bahwa lokasi yang memiliki kedalaman lebih dari $6 \mathrm{~m}$ terdapat di Mandawalai, Bucili dan Piyasili, dengan kedalaman mulai dari 8-10 m. Analisis parameter kesesuaian, untuk kegiatan wisata diving dengan kedalaman 8-10 m, memperlihatkan ketiga lokasi tersebut berada pada kelas S1 dan S2. Kelas kesesuaian dari ketiga lokasi ini memiliki luas daerah terumbu karang yang dapat dimanfaatkan sebagai wisata diving sebesar 7.84 ha.

Tabel 4. Hasil analisis kesesuaian ekowisata diving

\begin{tabular}{cccccc}
\hline Pulau & Lokasi & Luas (ha) & IKW (\%) & Kategori & Keterangan \\
\hline \multirow{2}{*}{ Liwo } & Mandawalai & 4.52 & $88.89 \%$ & $\mathrm{~S} 1$ & Sangat Sesuai \\
& Liwobumdi & 3.62 & $77.78 \%$ & $\mathrm{~S} 2$ & Sesuai \\
\hline \multirow{3}{*}{ Sayafi } & Bucili & 2.88 & $85.19 \%$ & $\mathrm{~S} 1$ & Sangat Sesuai \\
& Sowlolol & 3.10 & $87.04 \%$ & $\mathrm{~S} 1$ & Sangat Sesuai \\
& Kesusah & 3.51 & $87.04 \%$ & $\mathrm{~S} 1$ & Sangat Sesuai \\
& Piyasili & 0.44 & $94.44 \%$ & $\mathrm{~S} 1$ & Sangat Sesuai \\
\hline
\end{tabular}

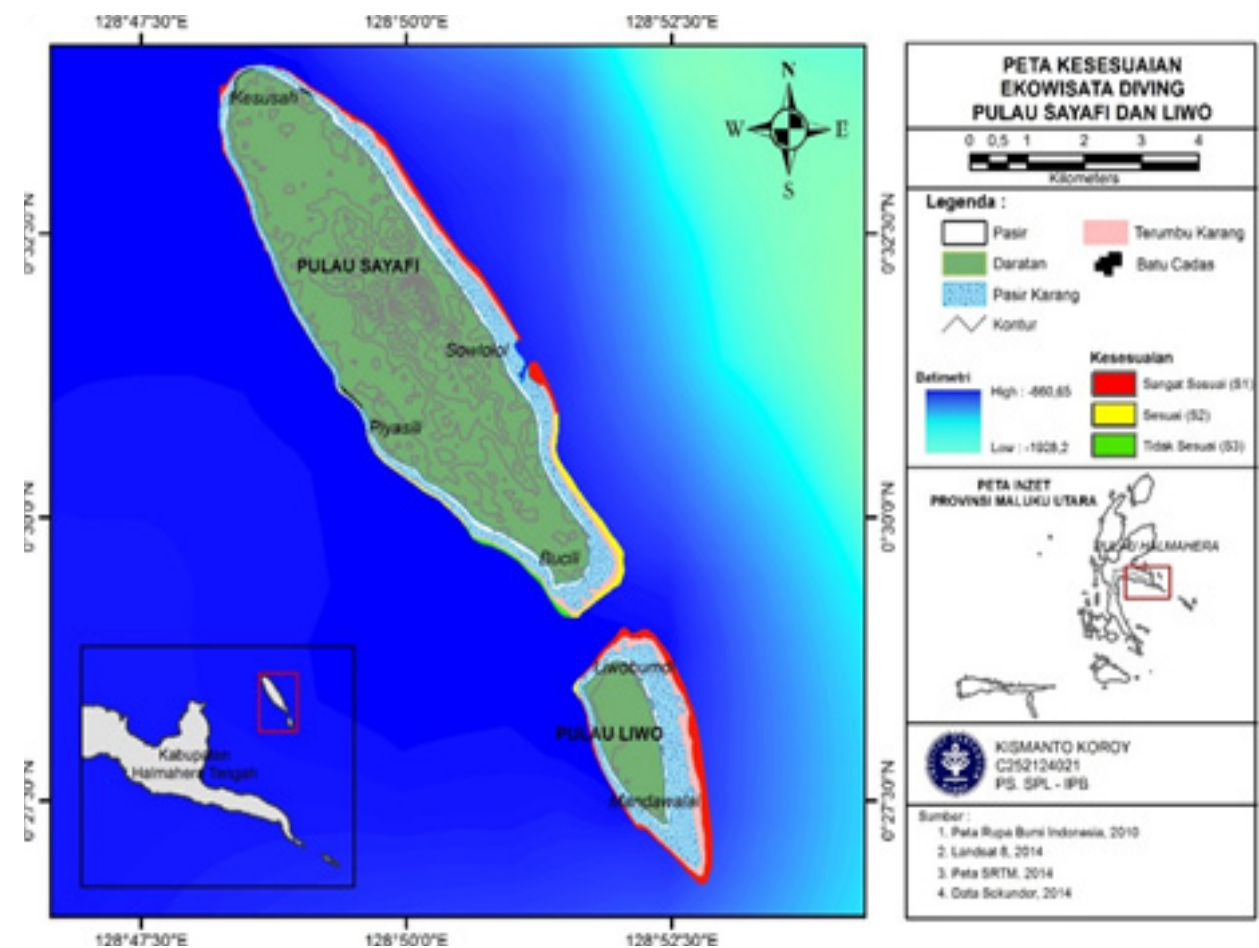

Gambar 4 Peta kesesuaian ekowisata diving di Pulau Sayafi dan Liwo 


\section{Wisata snorkeling}

Kelas kesesuaian untuk jenis kegiatan wisata snorkeling pada enam lokasi pengamatan, memiliki kategori kelas S1 dan S2. Kategori kelas S1 hanya terdapat di Kesusah, sedangkan kelas S2 terdapat di Mandawalai, Liwobumdi, Bucili, Sowlolol dan Piyasili. Analisis kesesuaian dilakukan dengan mempertimbangkan 7 parameter. Parameter yang digunakan dalam menghitung indeks kesesuaian wisata snorkeling adalah kecerahan perairan, tutupan komunitas karang, jenis lifeform, jenis ikan karang, kecepatan arus, kedalaman terumbu karang dan lebar hamparan datar karang. Matriks kesesuaian wisata snorkeling dan wisata diving hampir memiliki kesamaan parameter, hanya pada wisata snorkeling ditambahkan parameter lebar hamparan datar pantai. Meskipun parameter yang digunakan sama, akan tetapi nilai IKW setiap parameter tidak sama (Tabel 5).

Kesesuaian ekowisata bahari kategori wisata snorkeling memperlihatkan nilai IKW tertinggi berada di Piyasili dengan nilai $88.89 \%$ dan yang terendah berada di Liwobumdi 77.78\%. Meskipun hasil analisis menunjukkan kelas kesesuaian pada 6 lokasi pengamatan berada dalam kategori S1 dan S2, akan tetapi dalam pemanfaatan ekowisata bahari untuk kegiatan snorkeling hanya dapat dilakukan pada kedalaman tertentu. Pertimbangan parameter kedalaman terumbu karang untuk jenis kegiatan snorkeling, dimaksudkan agar aktifitas pengunjung yang melakukan snorkeling tidak menyentuh dan menginjak terumbu karang (Gambar 5).

Perhitungan kesesuaian wisata snorkeling di Liwobumdi, Bucili dan Sowlolol menunjukkan indeks kesesuaian kawasan dengan kategori S2, sedangkan kategori
S1 terdapat di Mandawalai, Kesusah, dan Piyasili. Kualitas parameter yang terdapat pada 3 lokasi tersebut, memiliki skor yang sangat mendukung kesesuaian wisata snorkeling. Parameter pendukung tutupan komunitas karang dengan skor 3 terdapat di Mandawalai (81.71\%), Sowlolol (80.27\%), Kesusah (80.34\%), dan Piyasili (81.39\%). sedangkan yang memiliki skor 2 (dua) terdapat di Liwobumdi dan Bucili dengan persentase komunitas karang sebesar (61.53\%-65.60\%). Meskipun di Liwobumdi dan Bucili memiliki tutupan komunitas karang paling rendah, akan tetapi parameter penting lain seperti kecerahan perairan dan jenis lifeform serta parameter lainnya dapat mendukung IKW untuk snorkeling. Parameter lain juga yang dapat mendukung kesesuaian wisata snorkeling di Liwobumdi dan Bucili antara lain jenis ikan karang sebanyak 34 jenis, kecepatan arus $0.28 \mathrm{~cm} /$ detik, kedalaman terumbu karang $4 \mathrm{~m}$ dan lebar hamparan datar karang sebesar 126m. Pengelolaan potensi sumberdaya alam Pulau Sayafi dan Liwo memerlukan perencanaan yang matang untuk pemanfaatan ekowisata bahari yang berkelanjutan. Hal ini didukung dengan parameter yang dikaji seperti potensi ekosistem terumbu karang, ikan karang dan parameter fisik lingkungan perairan di Pulau Sayafi dan Liwo. Jenis kegiatan ekowisata bahari dianalisis dengan menggunakan matriks kesesuaian dan GIS. Analisis kesesuaian ekowisata bahari dengan menggunakan GIS, kemudian dioverlay dan dibuat dalam bentuk peta kesesuaian ekowisata bahari di Pulau Sayafi dan Liwo, dengan mengikuti acuan (Hossain \& Das 2010) pada Gambar 6. Dari hasil analisis tersebut, diperoleh tingkat kesesuaian masing-masing jenis kegiatan ekowisata bahari dengan luasan sebesar 34.08 ha.

Tabel 5 Hasil analisis kesesuaian ekowisata snorkeling

\begin{tabular}{cccccc}
\hline Pulau & Lokasi & Luas (ha) & IKW (\%) & Kategori & Keterangan \\
\hline \multirow{2}{*}{ Liwo } & Mandawalai & 3.61 & $87.04 \%$ & $\mathrm{~S} 1$ & Sangat Sesuai \\
& Liwobumdi & 3.48 & $77.78 \%$ & $\mathrm{~S} 2$ & Sesuai \\
\hline \multirow{3}{*}{ Sayafi } & Bucili & 4.33 & $81.48 \%$ & $\mathrm{~S} 2$ & Sesuai \\
& Sowlolol & 3.63 & $81.48 \%$ & $\mathrm{~S} 2$ & Sesuai \\
& Kesusah & 0.70 & $87.04 \%$ & $\mathrm{~S} 1$ & Sangat Sesuai \\
& Piyasili & 0.26 & $88.89 \%$ & $\mathrm{~S} 1$ & Sangat Sesuai \\
\hline
\end{tabular}




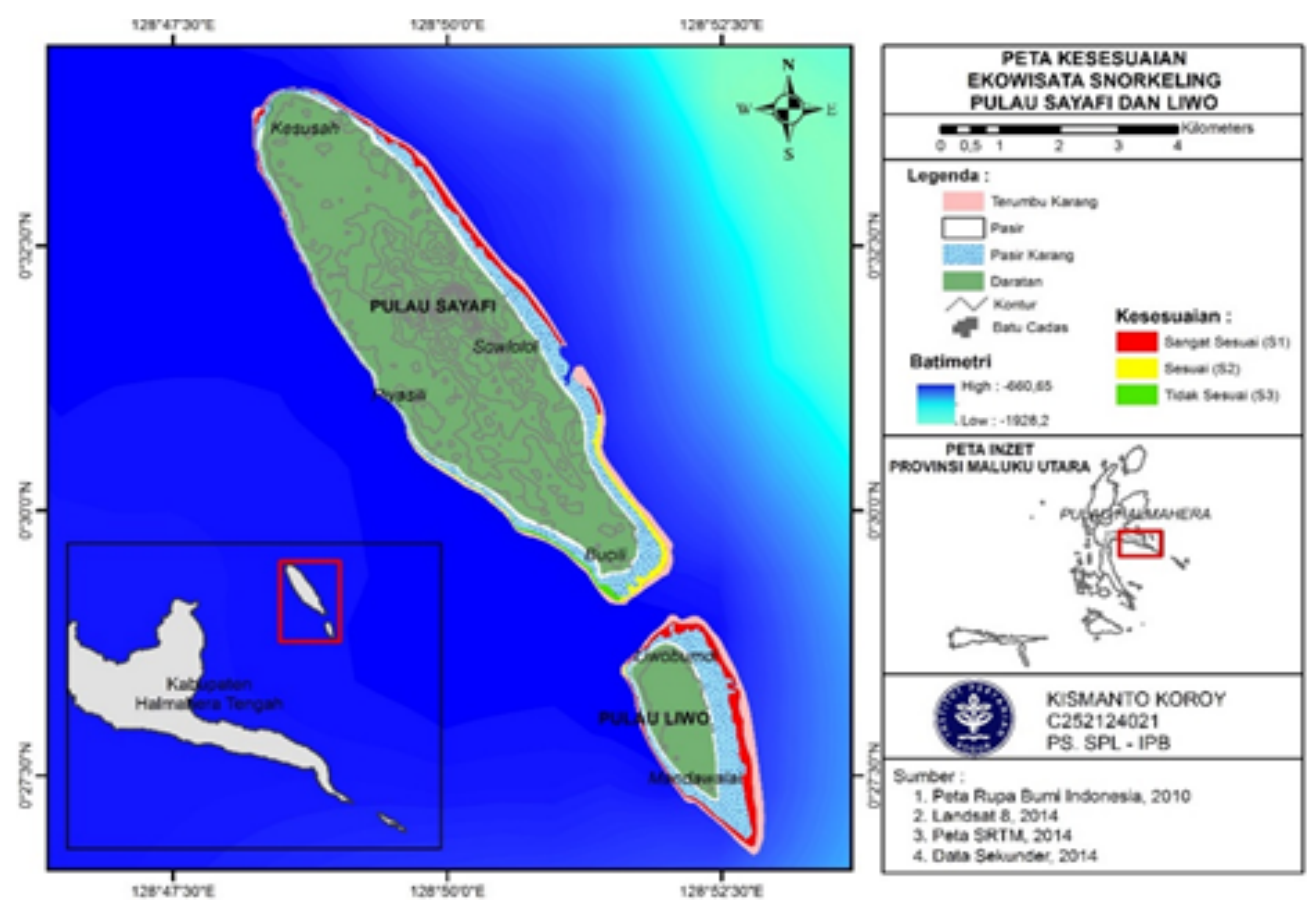

Gambar 5 Peta kesesuaian wisata snorkeling di Pulau Sayafi dan Liwo

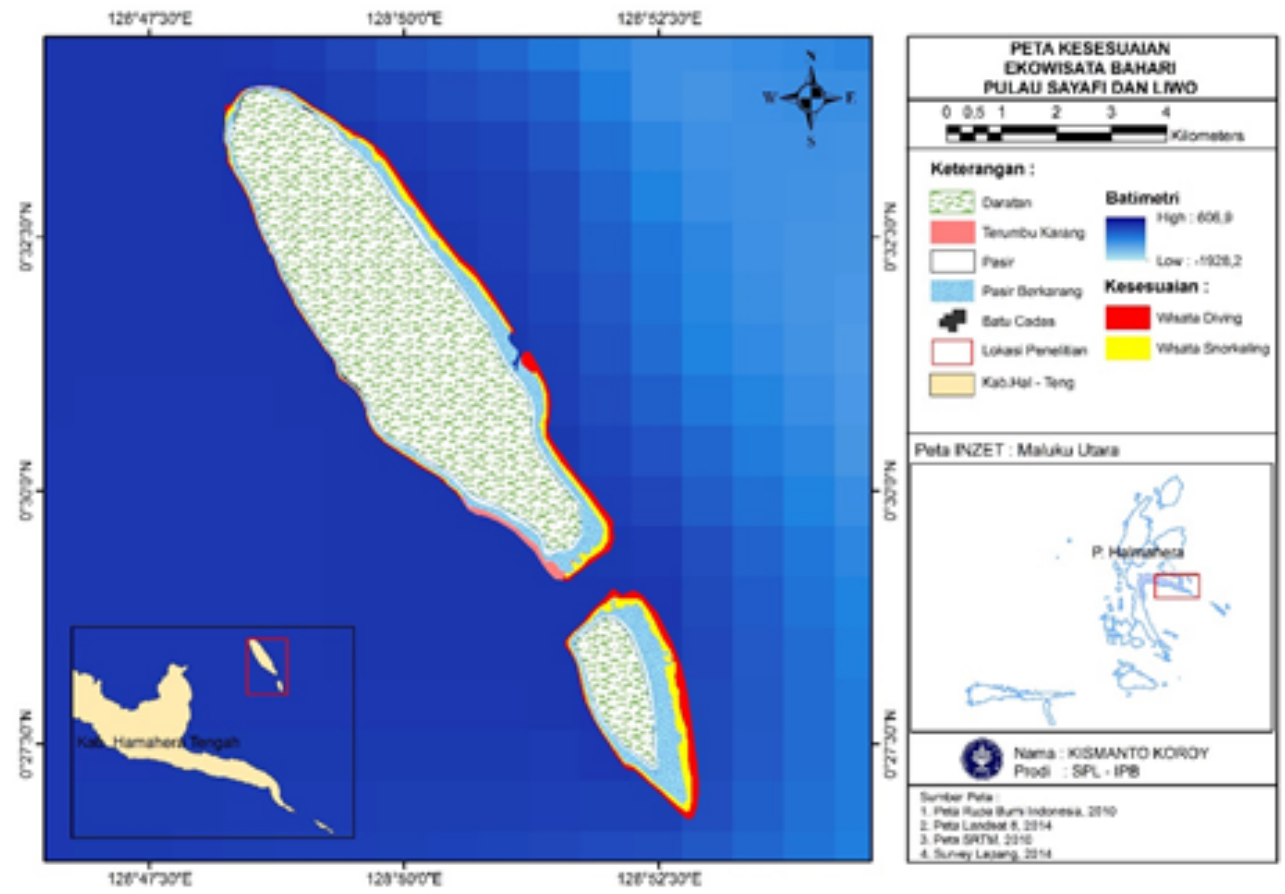

Gambar 6 Peta kesesuaian ekowisata bahari Pulau Sayafi dan Liwo

\section{Daya dukung ekowisata bahari}

UNEP (2001) mengatakan bahwa sebagian besar populasi masyarakat dunia mendiami wilayah pesisir, dan kebanyakan dari populasi tersebut memperoleh manfaat dari penggunaan sumberdaya pesisir dan laut. Aktifitas pemanfaatan sumberdaya alam untuk pemenuhan sistem sosial dan ekonomi akan berpengaruh pada proses lingkungan dan sistem ekologi. Blangy \& Mehta (2006), menambahkan bahwa langkah cepat dalam pengembangan pariwisata diseluruh dunia menyebabkan kerusakan tak terhitung untuk beberapa sistem ekologi yang terancam mengalami kepunahan. Oleh karena itu, kaitanya dengan pemanfaatan sumberdaya alam di Pulau Sayafi dan Liwo sebagai ekowisata bahari, diperlukan suatu pendekatan kritis untuk meminimalisir 
jumlah pungunjung.

Pengembangan ekowisata bahari di pulau-pulau kecil memiliki pengaruh terhadap ekosistem pesisir dan laut. Salah satu upaya untuk menyeimbangkan sumberdaya alam sebagai objek ekowisata bahari perlu memperhitungkan daya dukung kawasan DDK dan DDA. DDK ekowisata bahari, dilakukan untuk melihat kemampuan suatu kawasan dalam menampung pengunjung. Sedangkan DDA dilakukan untuk menghindari tekanan oleh pengunjung terhadap suatu ekosistem di pulau-pulau kecil. Analisis DDK dan DDA dibuat untuk kegiatan ekowisata bahari. Tratalos \& Austin (2001), menjelaskan bahwa aktifitas ekowisata diving dan snorkeling memiliki dampak yang cukup berpengaruh terhadap ekosistem karang, apabila jumlah penyelaman telah melebihi kapasitas, namun dilain sisi menurut (Ong \& Musa 2012) mengatakan bahwa perilaku penyelam ketika berada di bawah air masih sangat bertanggung jawab.

Daya dukung sebagai suatu konsep yang didasarkan pada pendekatan lingkungan dan merupakan bagian penting dalam kajian pengelolaan sumberdaya alam. Daya dukung didefinisikan sebagai kemampuan alam dalam mentolerir aktifitas manusia. Perhitungan daya dukung kawasan ekowisata bahari berdasarkan karakteristik sumberdaya dan peruntukannya. Yulianda et al. (2010) menyatakan bahwa daya dukung diving dan snorkeling ditentukan berdasarkan pada luas terumbu karang yang dapat dimanfaatkan, potensi ekologis pengunjung per satuan unit area yang digunakan untuk beraktifitas dan alam masih mampu untuk mentolerir kehadiran pengunjung dan prediksi waktu yang dibutuhkan untuk setiap jenis kegiatan (Tabel 6).

Perhitungan DDK untuk ekowisata bahari, didasarkan pada hasil analisis kesesuaian lahan tiap jenis kegiatan tertentu yang memiliki nilai kesesuaian berada pada kategori kelas S1 dan S2. Keseluruhan kelas kesesuian untuk jenis kegiatan diving dan snorkeling di Pulau Sayafi dan Liwo termasuk dalam kategori S1 dan S2. Perhitungan DDK untuk ekowisata bahari menunjukkan bahwa jenis kegiatan diving memiliki daya tampung sebanyak 723 orang/hari dengan luasan sebesar 18.07ha. Luas kawasan untuk snorkeling sebesar 16.01ha dengan kemampuan menerima kunjungan sebanyak 639 orang/hari.

Hasil analisa daya dukung ekowisata bahari di Pulau Sayafi dan Liwo, memperlihatkan jumlah daya tampung orang/hari mencapai 1362, untuk 2 jenis kegiatan. Oleh karena itu, dalam pemanfaatannyaharus tetap memperhatikan faktor fisik lingkungan sebagai objek dari perjalanan untuk ekowisata. Analisis daya dukung ditujukan pada pengembangan wisata bahari dengan memanfaatkan potensi sumberdaya pesisir, pantai dan pulau-pulau kecil secara lestari (Yulianda et al. 2010). Menurut Bengen (2012), menyatakan bahwa daya dukung sebagai tingkat pemanfaatan sumberdaya alam atau ekosistem secara berkesinambungan tanpa menimbulkan kerusakan sumberdaya alam dan lingkungannya.

Perhitungan DDK dan DDA untuk ekowisata bahari menggunakan pendekatan kawasan dan ekosistem, masing-masing memiliki nilai yang berbeda. Pendekatan kawasan untuk melihat kemampuan suatu kawasan pulau-pulau kecil dalam menampung pengunjung, sedangkan pendekatan ekosistem untuk melihat kapasitas adaptif ekosistem terumbu karang dalam mentoleransi pengaruh eksternal. Daya dukung adaptif dilakukan untuk mengetahui seberapa besar kamampuan suatu ekosistem di pulau kecil dapat ditoleransi setiap kegiatan yang berlangsung sehingga fungsi-fungsi sistem suatu pulau tetap berjalan (Subur 2012). Daya dukung adaptif dapat dihitung setelah mendapatkan nilai IDTK dan nilai DDK. Berdasarkan hasil tersebut, kemudian digunakan nilainya untuk menentukan DDA bagi suatu peruntukkan berdasarkan daya dukung kawasan. Daya dukung adpatif ekosistem terumbu karang juga digunakan untuk mengoreksi jumlah kunjungan berdasarkan DDK. Hal ini bertujuan untuk menjaga keseimbangan ekosistem pada suatu pulau kecil yang akan dimanfaatkan sebagai ekowisata bahari. Dengan pendekatan tersebut, diharapkan dapat menjaga keberlangsungan ekologi dan keberlanjutan ekowisata bahari di Pulau Sayafi dan Liwo. Perbandingan daya dukung kawasan dan daya dukung adaptif berdasarkan tingkat kesesuaian ekowisata bahari untuk wisata diving dan snorkeling, ditampilkan pada Gambar 7 dan Gambar 8.

Berdasarkan Gambar 7 dan Gambar 8 dapat diinformasikan bahwa distribusi pengunjung berdasarkan daya dukung kawasan dan daya dukung adaptif untuk ekowisata bahari dengan jenis kegiatan wisata diving dan snorkeling yang dapat 
dimanfaatkan di Pulau Sayafi dan Liwo. Telah terjadi perubahan kapasitas pengunjung antara DDK dan DDA setelah dikoreksi. Hal ini dimaksudkan agar meminimalisir tekanan eksternal dari aktifitas pengunjung dalam memanfaatkan ekosistem terumbu karang dan ekosistem pesisir lainnya sebagai objek untuk berwisata. Pendekatan pengelolaan ekowisata bahari yang berkelanjutan perlu memperhatikan faktor pembatas untuk masing-masing jenis kegiatan yang akan di manfaatkan. Daya dukung ekowisata bahari juga di harapkan dapat menyeimbangkan tingkat aktifitas pengunjung untuk setiap kegiatan.

Tabel 6 Nilai DDK dan DDA untuk ekowisata bahari Pulau Sayafi dan Liwo

\begin{tabular}{ccccc}
\hline No & Jenis Kegiatan & Luas Area & $\begin{array}{c}\text { Daya Dukung } \\
\text { Kawasan }\end{array}$ & Daya Dukung Adaptif \\
\hline 1 & Wisata diving & 18.07 ha & 723 & 260 \\
2 & Wisata snorkeling & 16.01 ha & 639 & 231 \\
\hline Total & & 1362 Orang/hari & 491 Orang/hari \\
\hline
\end{tabular}

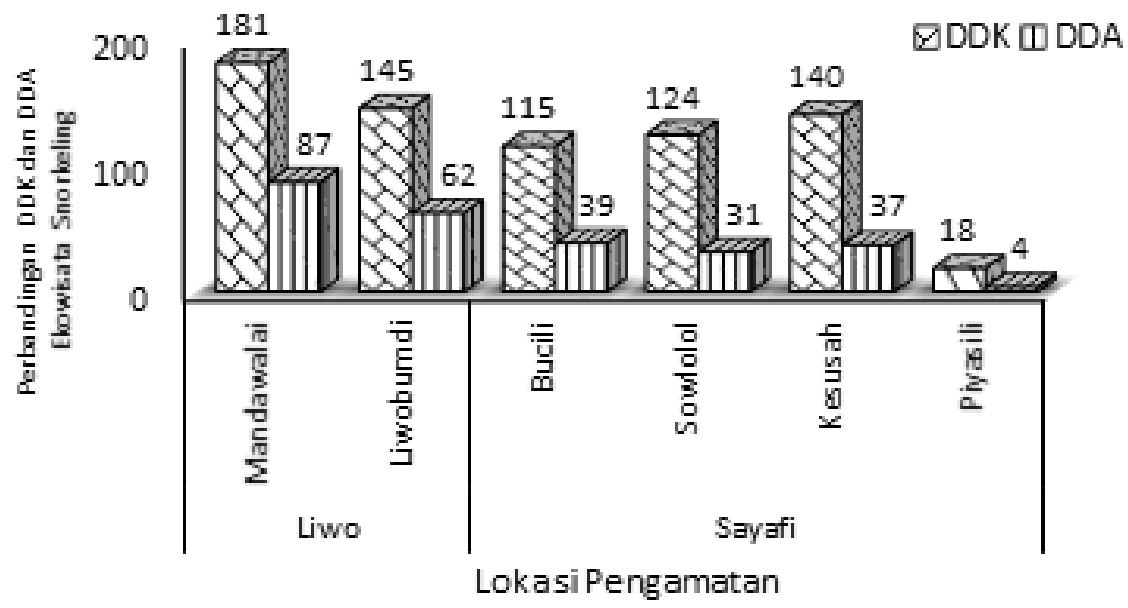

Gambar 7 Perbandingan DDK dan DDA untuk ekowisata diving

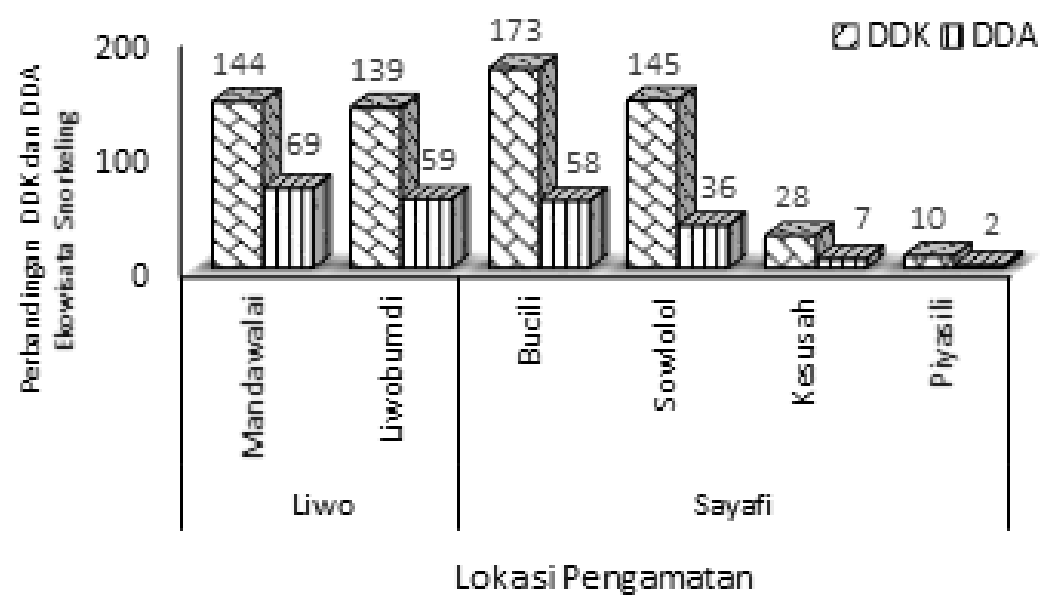

Gambar 8 Perbandingan DDK dan DDA untuk ekowisata snorkeling 


\section{KESIMPULAN}

Kesesuaian ekowisata bahari untuk wisata diving dan snorkeling, terdapat dua kategori kesesuaian, diantaranya kelas Sesuai (S2) dan kelas Sangat Sesuai (S1). Wisata diving dengan luasan 18.07 ha, memiliki kelas kesesuaian kategori S1 terdapat di Mandawalai, Bucili, Sowlolol, Kesusah dan Piyasili, sedangkan kelas kesesuaian kategori S2 terdapat di Liwobumdi. Ekowisata snorkeling dengan luasan 16.01 ha, termasuk dalam kategori S1 terdapat di Mandawalai, Kesusah dan Piyasili, sedangkan kategori S2 berada di Liwobumdi, Bucili dan Sowlolol.

Daya dukung kawasan (DDK) pulau Sayafi dan Liwo sebagai ekowisata bahari dengan jenis kegiatan wisata diving memiliki kapasitas pengunjung sebanyak 723 orang, dan daya dukung adaptif (DDA) 260 orang, dengan potensi ekologis 18.07 ha. Wisata snorkeling memiliki DDA sebanyak 231 orang dari DDK 639 orang, memiliki potensi ekologis 16.01 ha. Jadi total keseluruhan pengunjung untuk ekowisata diving dan snorkeling dengan pendekatan ekologi (DDA) di pulau Sayafi dan Liwo sebanyak 491 orang/ hari.

\section{UCAPAN TERIMA KASIH}

Ucapan terima kasih penulis sampaikan kepada Pemerintah Provinsi Maluku Utara, Pemerintah Kabupaten Halmahera Tengah, Bappeda, Dinas Kelautan dan Perikanan Kabupaten Halmahera Tengah serta instansi terkait yang telah memberikan dukungan data dalam penelitian ini. Ucapan terima kasih juga diucapkan kepada masyarakat di Kecamatan Patani Utara atas dukungan dan partisipasinya selama penelitian.

\section{DAFTAR PUSTAKA}

Bengen DG, Retraubun SW Alex, Saad S. 2012. Menguak Realitas dan Urgensi Pengelolaan Berbasis Eko-Sosio Sistem Pulau-Pulau Kecil. Bogor (ID): Pusat Pembelajaran dan Pengembangan Pesisir dan Laut (P4L).

Blangy S, Mehta H. 2006. Ecotourism and ecological restoration. Nature Conservation. 14 (2006) 233-236.

Dahuri R. 2009. Strategi Pengembangan Ekowisata Bahari. [internet] [diunduh pada tanggal 3 Sep 2015]; tersedia pada: https:// rokhmindahuri. wordpress.com/ tag/ pariwisatabahari/

[DKP] Dinas Kelautan dan Perikanan Provinsi Maluku Utara, Bekerjasama Dengan CV. Panca Asri Planning Consultant, 2008. Laporan akhir, Penyusunan Rencana Tata Ruang Laut, Pesisir Dan Pulau-Pulau Kecil Kabupaten Halmahera Tengah Tahun 2008. Ternate (ID): DKP Malut.

[DKP] Dinas Kelautan dan Perikanan Provinsi Maluku Utara, 2012. Identifikasi Calon Kawasan Konservasi Perairan Pulau Jiew, Provinsi Maluku Utara Tahun 2012. Ternate (ID): DKP Malut. English S, Wilkinson S and Baker V. 1997. Survey Manual for Tropical Marine Resources. Australian Institut of Marine Science. London (BG): Townsville.

Gladstone W, Curley B, Shorki MR. 2013. Enviromental impacts of tourism in the Gulf and the Red Sea. Marine Pollution Bulletin. 09 (2012)017. 375388.

Gomez ED, Yap HT. 1988. Monitoring Reef Condition in Kenchington, R.A. and B. E. T. Hudson (ed.): Coral Reef Management Hand Book. Jakarta (ID) UNESCO Regional Office for Science and Technology for South East Asia.

Gossling S. 1999. Ecotourism: a Means to Safeguard Biodiversity and Ecosystem Functions. Ecological Economics. 12 (99) -9. 303-320.

Hossain SM, Das NG. 2010. GIS-based multi-criteria evaluation to land suitability modelling for giant prawn (Macrobrachium rosenbergii) farming in Companigonj Upazila of Noakhali, Bangladesh. Computers and Electrics in Agriculture. 10 (2009):003. 172186.

Lindberg K, Hawkins DE. 1995. Ekoturism: Petunjuk Untuk Perencana dan Pengelola. The Ecoturism Society. North Bennington, Vermont. Penerjemah. Jakarta (ID): Yayasan Alam Mitra Indonesia. Terjemahan dari: The Ecoturism Society.

Nontji A. 2009. Laut Nusantara. Jakarta (ID): Djambatan.

Nurjanah, Abdullah A, Kustiariyah. 2011. Pengetahuan dan Karakteristik Bahan Baku Hasil Perairan. Bogor (ID): IPB Pr.

Nybakken JW. 1998. Biologi Laut Suatu Pendekatan Ekologis. Penerjemah. M. Ediman, Koesoebiono, DG. Bengen, 
M. Hutomo, S. Sukardjo. Jakarta (ID). PT. Gramedia. Terjemahan dari: Marine Biology An Ecological Approach.

Odum. 1994. Dasar-Dasar Ekologi. Yogyakarta (ID) Gadjah Mada University Pr.

Ong TF, Musa G. 2012. Examining the influences of experience, personality and attitude on SCUBA divers' underwater behaviour: A structural equation model. Tourism Management. 02 (2012): 007. 15211534.

[PERMENDIKBUD] Peraturan Menteri Kebudayaan Pariwisata. Nomor: KM.67/UM.001/MKP/2004. Tentang pedoman umum pengembangan pariwisata di pulau-pulau kecil. Jakarta (ID): Menteri Kebudayaan dan Pariwisata.

Ross S, Wall G. 1999. Evaluating ecotourism: The case of North Sulawesi, Indonesia. Tourism Managrment. 5177(99): 400. 673-682.

Sitomorang DBM, Mirzanti IR. 2012. Social entrepreneurship to develop ecotourism. Procedia Economics and Finance. 4 (2012) 398-405.

Subur R. 2012. Daya Dukung Ekowisata Dengan Pendekatan Kapasitas Adaptif Ekologi Di Pulau-Pulau Kecil, Kasus Gugus Pulau Guraici Kabupaten Halmahera Selatan Provinsi Maluku Utara. [Disertasi]. Bogor (ID): Institut Pertanian Bogor.

[TIES] The International Ecoturism Society. 2015. What is Ecotourism. [internet] [diunduh 31 Aug 2015]; tersedia pada: https:// www. ecotourism. org /what -is-ecotourism.

Tratalos JA, Austin TJ. 2001. Impacts of recreational SCUBA diving on coral communities of the Caribben island of Grand Cayman. Biological Conservation. 3207(01): 8. 4-5.

Tsaur SH, Lin YC, Lin JH. 2006. Evaluating ecotourism sustainability from the integrated perspective of resource, community and tourism. Tourism Management. 02 (2005): 006.

Wikipedia. 2015. Ekowisata. [internet]. [diunduh 2015 Sept 3]. Tersedia pada: https://id.wikipedia.org/wiki/ Ekowisata.

Yulianda F. 2007. Ekowisata Bahari Sebagai Alternatif Pemanfaatan Sumberdaya Pesisir Berbasis Konservasi. Seminar Sains pada Departemen MSP, FPIK IPB. 21 Februari 2007; Bogor, Indonesia. Bogor (ID): Departemen MSP IPB.

Yulianda F, Fahrudin A, Hutabarat AA, Harteti S, Kusharjani, Kang HS. 2010. Pengelolaan Pesisir dan Laut Secara Terpadu (Integrated Coastal and Marine Management). Bogor (ID): Pusdiklat KehutananDepartemen Kehutanan Ri, SecemKorea International Cooperation Agency.

Zhang H, Lei SL. 2012. A Structural Model of Reaident's Intention to Participate in Ecotourism: The Case of a Wetland Community. Tourism Managrment. 09 (2011): 012. 916-925. 